原著

\title{
体内膜細胞診における腺腫性増殖症および 高分化型体内膜腺癌の判定基準について
}

\author{
東京都がん検診センター細胞診1), 同 婦人科2), 杏林大学保健学部細胞診断学教室 ${ }^{3)}$ \\ 石井 保吉 ${ }^{1,3)}$ 藤井 雅彦1) 佐久間市朗 ${ }^{1)}$ 桐谷 寿子1) \\ 深堀世津子 ${ }^{1)}$ 若林 富枝 ${ }^{1)}$ 杉下 匡 $^{1)}$ 藤吉 啓造 ${ }^{2}$ \\ 石田 禮載 ${ }^{2}$ 大村 峯夫 ${ }^{2}$
}

体内膜細胞診における腺腫性増殖症と高分化型体内膜腺癌の質的判定基準を設定するため，全面 搔爬による組織診で確認された腺腫性増殖症 15 症例 26 検体, 術後の組織診で確認された高分化型 体内膜腺癌 16 症例 26 検体を用い，細胞集塊の形態および構造について検討を行い，以下の結果を 得た。

1）樹枝状細胞集塊は腺腫性増殖症では $3.8 \%$ にみられたのみであったのに対し，G1腺癌にお いては 73.1\% に認められた。乳頭状細胞集塊は腺腫性増殖症, G 1 腺癌ともに全例に認められた。

2）集塊内腺腔の密な検体は，腺腫性増殖症で $23.1 \%, \mathrm{G} 1$ 腺癌で $84.6 \%$ であった。

3）腺腔の back to back は腺腫性増殖症で $23.1 \%$, G 1 腺癌では $88.5 \%$ に認められた。

4）腺腔内乳頭状増殖は, 腺腫性増殖症では $34.6 \%, \mathrm{G} 1$ 腺癌では $84.6 \%$ に認められた。

以上より腺腫性増殖症と $\mathrm{G} 1$ 腺癌の細胞学的判定には, 乳頭状細胞集塊および樹枝状細胞集塊の 有無，およびそれらの構造異型を観察することが重要であると考えた.

Key words : Endometrium—Cytology—Adenocarcinoma-Adenomatous hyperplasia

\section{I.はじめに}

Criteria on cytodiagnosis of adenomatous hyperplasia and well differentiated adenocarcinoma of the endometrium

Yasuyoshi ISHII ${ }^{1,3)}$, C.T., I.A.C., Masahiko FUJII' ${ }^{1)}$, M.D., M.I.A.C., Ichiro SAKUMA ${ }^{1)}$, C.T., I.A.C., Toshiko KIRITANI ${ }^{1}$, C.T., I.A.C., Setsuko FUKAHORI ${ }^{11}$, C.T., Tomie WAKABAYASHI $^{1)}$, C.T., I.A.C., Tadashi SUGISHITA ${ }^{1)}$, M. D., M.I.A.C., Keizo FUJIYOSHI ${ }^{2)}$, M.D., Norikoto ISHIDA ${ }^{2)}$, M.D., Mineo OMURA ${ }^{2)}$, M.D.

${ }^{1)}$ Division of Cytology, ${ }^{2}$ Division of Gynecology, Tokyo Metropolitan Cancer Detection Center

${ }^{3)}$ Department of Cytology, Kyorin University School of Health Sciences

論文別刷請求先 $\mathbb{E} 183$ 東京都府中市武蔵台 2 の 92 多

摩がん検診センター 石井保吉

平成 3 年 1 月 23 日受付

平成 3 年 4 月 12 日受理
子宮内膜増殖症の前癌病変としての性格が明らかに なるにつれ，子宮体内膜における増殖性病変の質的判 定が重要視または要求されるようになってきた。しか し，細胞標本においては，細胞の質的判定が容易では なく,診断に困難を生ずることが少なくない ${ }^{6,8,10)}$.そこ でわれわれは，体内膜組織標本の連続切片を用いて， 高分化型体内膜腺癌（以下 $\mathrm{G} 1$ 腺癌）および関連病変 の組織構築上の特徵を抽出し, 細胞標本の観察におい ては，細胞個々の形態のみならず，上皮細胞と間質細 胞の明確な同定と, 顕微鏡の微動装置を十分に活用し た三次元的な細胞構築の読み方が重要であることを強 調し, 報告してきた ${ }^{3)}$. 今回は, 内膜細胞診の標本を検 鏡するにあたって内膜増殖症以上の病変をいかに確実 
に拾い上げるか，および内膜増殖症と G 1 腺癌とをい かに鑑別判定するかについて詳細な検討を行ったので 報告する。

\section{II. 対象および方法}

全面搔爬による組織診で確認された腺腫性増殖症 15 症例（41～53 歳，平均 47.9 歳） 26 検体，術後の組 織診で確認された $\mathrm{G} 1$ 腺癌 16 症例（42～62 歳，平均 52.8 歳) 26 検体を対象にした。また，対照として，組 織診で増殖期内膜とされた 16 症例（31～52 歳，平均 43.3 歳) 16 検体についても同様に検討を加えた。なお， 今回用いた細胞標本は全て増淵式吸引器具またはエン ドサイトによって採取された材料を生食水の中に洗い 出し，遠心沈殿させ細胞を擦り合わせ法により塗抹し たものである。

検索項目は, (1) 樹枝状細胞集塊ないし乳頭状細胞集 塊の出現頻度, (2) 集塊内多層化腺腔, (3) 腺腔の back

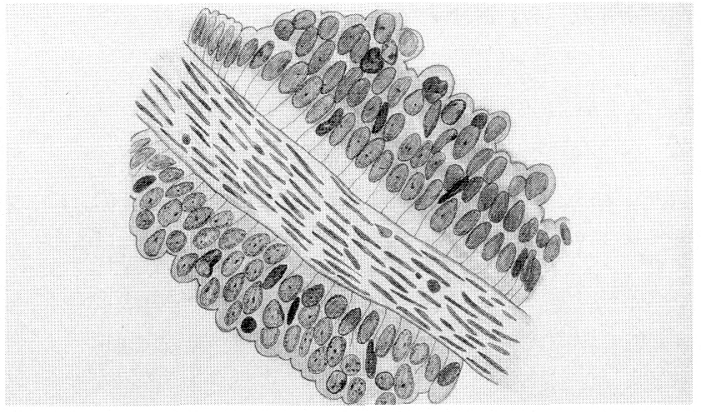

写真 1 体内膜腺癌 $\mathrm{G} 1$ のシェーマ 長棈円形の核を呈する紡鍾形細胞（Stromal A) の束に直角に 上皮細胞が結合している

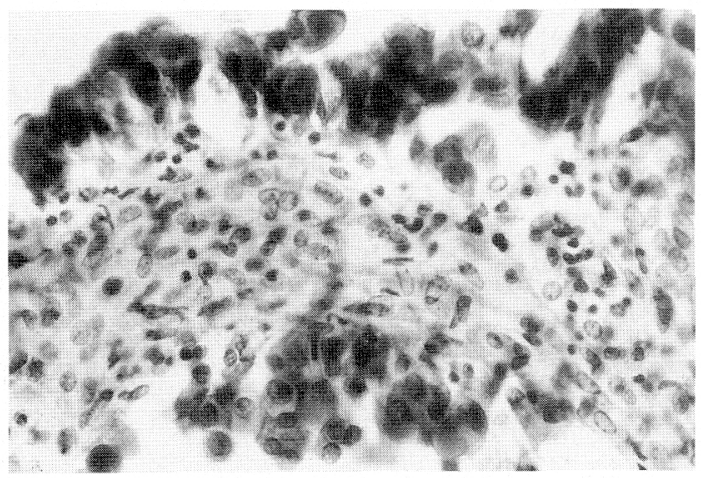

写真 2 体内膜腺癌 $\mathrm{G} 1$ 例

Stromal A を芯にするように結合して認められる上皮細胞集 塊 (Pap. 染色, $40 \times 3.3)$ to back の所見, および (4) 腺腔内乳頭状增殖の 4 項 目である。なお，(1)の樹枝状細胞集塊とは長楕円形の 核をもった紡鍾形細胞（以下 Stromal A とする）の束 を中心有し，それに直角に細胞が配列して認められ る細胞集塊で，分岐するように増殖しているものとし た(写真 1 3)。また, 細胞集塊の辺緑に濃染性の間質 細胞の直接付着を伴わず，しかも細胞集塊の芯氾 Stromal A が明瞭でないものを乳頭状細胞集塊とし た(写真 4). (2)の集塊内多層化腺腔については, 集塊 内に 2 層以上の上皮細胞で囲まれた腔を有するものに 限定した(写真 5 )。また，(2) の腺腔が隣接して認めら れる際には腺腔の back to back の所見（3)）とし(写 真 6 ), (2) の腺腔壁から細胞集塊が乳頭状偪殖して いるものを腺腔内乳頭状増殖（4)）と名付けた（写真 7 ).

\section{III. 結 果}

1）樹枝状・乳頭状細胞集塊の出現率

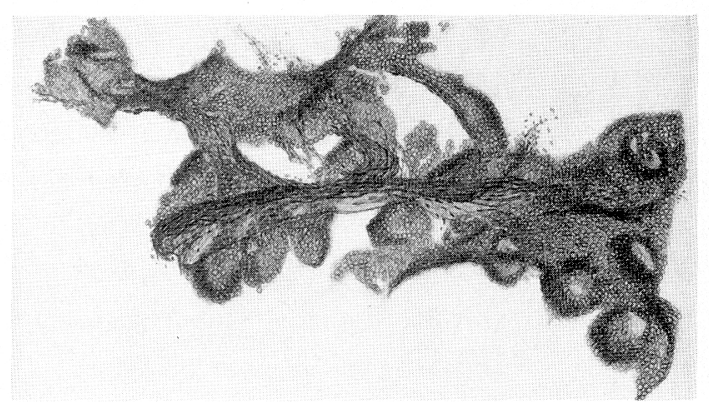

写真 3 体内膜腺癌 $\mathrm{G} 1$ のシェーマ

Stromal A を軸に乳頭状の分岐, 腺腔形成（構造異型）が観 察される

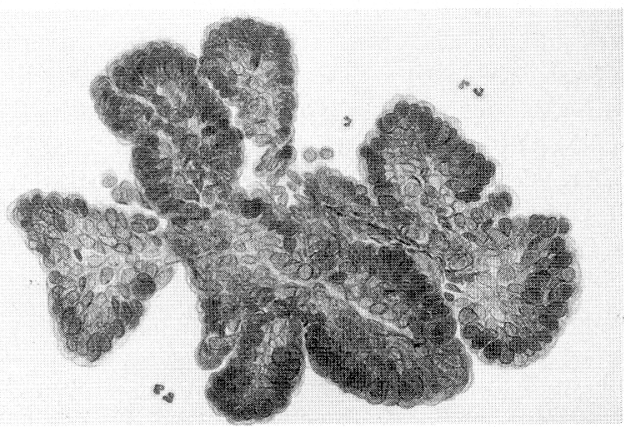

写真 4 腺腫性増殖症のシェーマ

細胞集塊の辺縁に濃染性の間質細胞の直接付着を伴わず，しか も細胞集塊の芯に Stromal A が不明瞭である 


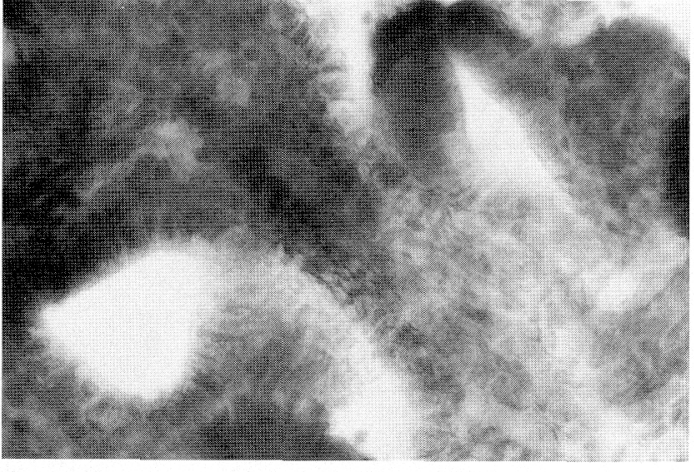

写真 5 腺腫性増殖症例

2 層以上の上皮細胞からなる細胞集塊の中に腺腔形成がみられ る(Pap. 染色, $40 \times 3.3$ )

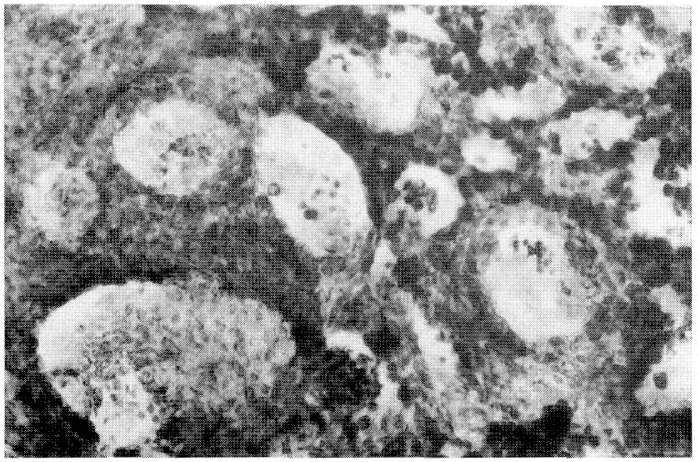

写真 6 体内膜腺癌 $\mathrm{G} 1$ 例

腺腔が密に隣接して認められる（Pap. 染色，40×3.3）

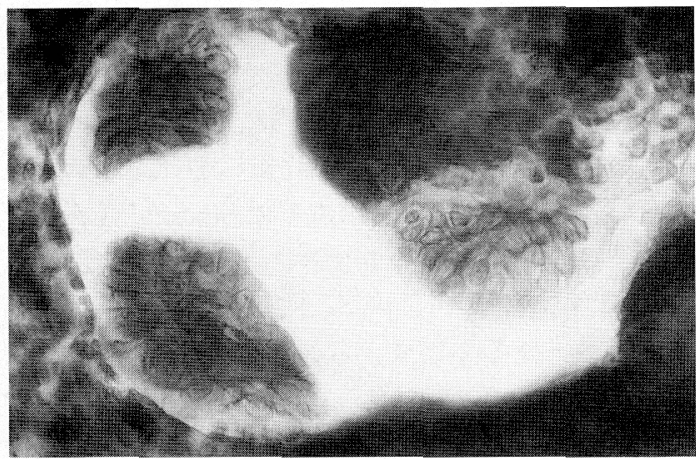

写真 7 腺腫性增殖症例

腺腔壁から細胞集塊が乳頭状に增殖して認められる（Pap. 染 色, $63 \times 2.5$ )

樹枝状細胞集塊は, 腺腫性増殖症では 26 検体中わず かに 1 検体 (3.8\%)にみられたのみであったのに対し， $\mathrm{G} 1$ 腺癌においては 26 検体中 19 検体 (73.1\%) に認め られた。乳頭状細胞集塊は腺腫性増殖症, G 1 腺癌とも
表 1 細胞集塊の形態

\begin{tabular}{cccc}
\hline \hline 組 織 型 & 検体数 & \multicolumn{2}{c}{ 集塊の出現例数 } \\
\cline { 3 - 4 } & & 樹枝状集塊 & 乳頭状集塊 \\
\hline 腺腫性増殖症 & 26 & $\begin{array}{c}1 \\
(3.8 \%)\end{array}$ & $\begin{array}{c}26 \\
100 \%) \\
\text { 高分化型腺癌 }\end{array}$ \\
\hline
\end{tabular}

表 2 細胞集塊に抢ける腺腔の出現状態

\begin{tabular}{|c|c|c|c|c|}
\hline \multirow{2}{*}{ 組 織 型 } & \multirow{2}{*}{ 検体数 } & \multicolumn{3}{|c|}{ 集塊内多層化腺腔* } \\
\hline & & H & + & \pm \\
\hline 腺腫性増殖症 & 26 & $\begin{array}{c}6 \\
(23.1 \%)\end{array}$ & $\begin{array}{c}16 \\
(61.5 \%)\end{array}$ & $\begin{array}{c}4 \\
(15.4 \%)\end{array}$ \\
\hline 高分化型腺癌 & 26 & $\begin{array}{c}22 \\
(84.6 \%)\end{array}$ & $\begin{array}{c}4 \\
(15.4 \%)\end{array}$ & $\begin{array}{c}0 \\
\left(\begin{array}{ll}0 & \%\end{array}\right)\end{array}$ \\
\hline 増殖期内膜 & 16 & 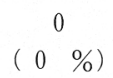 & $\begin{array}{c}0 \\
\left(\begin{array}{c}0 \% \\
0\end{array}\right)\end{array}$ & $\begin{array}{c}16 \\
(100 \%)\end{array}$ \\
\hline & & & $\begin{array}{l}+: 10 \text { 個L } \\
+: 5 \sim \\
\pm: 4 \text { 個上 }\end{array}$ & $\begin{array}{l}/ 10 \text { 倍視野 } \\
/ 10 \text { 倍視野 } \\
/ 10 \text { 倍視野 }\end{array}$ \\
\hline
\end{tabular}

に全例飞認められた(表 1 )。一方，増殖期内膜につい ては，乳頭状細胞集塊は 16 症例中 4 症例 (25.0\%) に 認められたが，樹枝状細胞集塊は 1 検体もみられなか つた。

2）集塊内多層化腺腔

腺腫性増殖症では, 集塊内腺腔が対物レンズ 10 倍で 1 視野に平均 10 個以上みられたものは，26 検体中 6 検体 $(23.1 \%) ， 5 ９$ 個みられたものは 16 検体 (61.5\%)，4 個以下しかみられなかったものは 4 検体 (15.4\%) であった。一方, G 1 腺癌は 26 検体中, 各久 22 検体 $(84.6 \%) ， 4$ 検体 (15.4\%)，0 検体で，腺腔 の目立つものが高頻度に認められた(表 2 )。なお，増 殖期内膜においては腺腔に乏しく，いずれも 4 個以下 であった。

3）腺腔の back to back

腺腔の back to back については腺腫性増殖症で 26 検体中 6 検体 $(23.1 \%)$ に，G 1 腺癌では 26 検体中 23 検体（88.5\%）に認められた。増殖期内膜では 1 検体 も認められなかった。

4）腺腔内乳頭状增殖

腺腫性増殖症では, 腺腔内乳頭状増殖が対物レンズ 10 倍で 1 視野に $1 \sim 4$ 個みられたものは 26 検体中 9 
表 3 細胞集塊における腺腔の形態

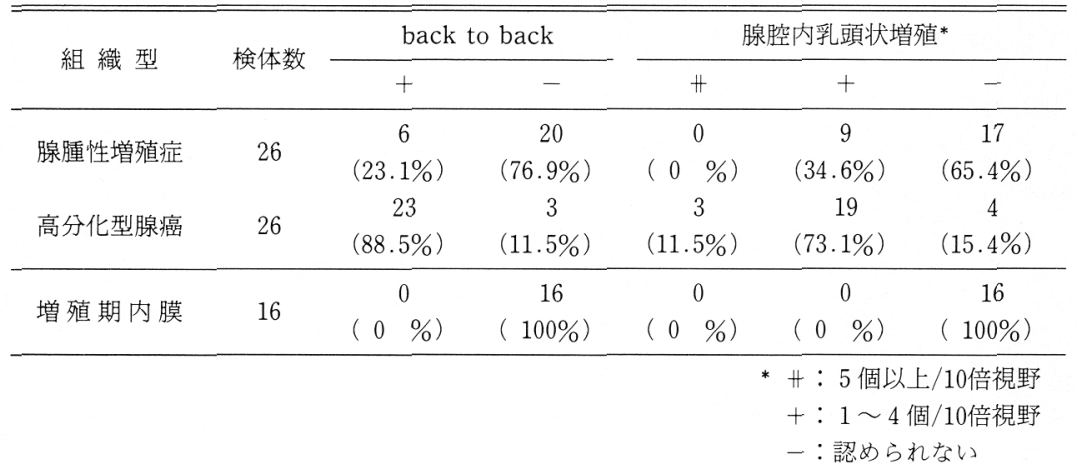

検体 $(34.6 \%)$, 認められなかったものは 17 検体 (65.4\%)であった。一方，G 1 腺癌 26 検体中では， 10 倍視野で 5 個以上認められたものが 3 検体（11.5\%）, 1 4 個のものが 19 検体 $(73.1 \%)$ ，認められないもの が 4 検体（15.4\%）であった（表 3$)$ 。な押，增殖期内 膜では腺腔内乳頭状増殖は 1 検体も認められなかっ た.

\section{IV. 考案}

体内膜細胞診における細胞像の読み方についてはこ れまで多くの報告がなされている。しかし諸家の報告 では標本の背景, 細胞の散在性, 核間距離, 核密度, 核の大小不同，核小体の数などを主体に判定している のがほとんどである ${ }^{1,2,4,5,7,9,11)}$ 。このような細胞の判定 基準は，細胞異型の目立つ体内膜腺癌すなわち G 2, G 3 の腺癌の判定には十分と思われる。しかし, 藏本 $ら^{6)}$ の報告にもあるように, G 1 腺癌では細胞異型が乏 しいため,このような判定基準では陰性と判定される 症例も少なくない けではなく構造異型を主体に考え，細胞集塊からの樹 枝状，乳頭状の分岐の観察が重要であること，すなわ ち構造をよく観察することの有用性を強調してき $た^{3)}$.

構造異型について観察するには，まず第一に間質細 胞と上皮細胞との的確な識別が必要と思われる．正常 子宮内膜に由来する間質細胞としては，われわれは便 宜上 3 種類にわけて考えている．第一の間質細胞は既 に説明した長棈円形の核を有する紡鍾形細胞，すなわ ち Stromal A であり，第二は類円・楕円の核形を有し 極性の認められない間質細胞で，Stromal B と名付け ているものである(写真 8$)$. 第三は体内膜腺の周囲に

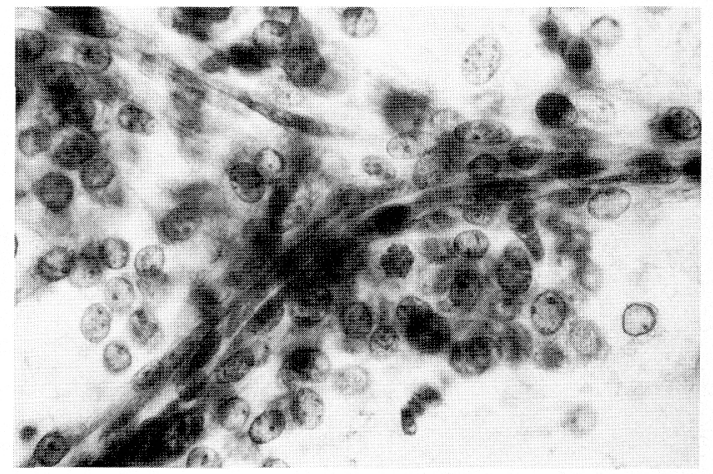

写真 8 子宮体内膜の間質細胞

長棈円形の核を有する紡鍾形細胞（Stromal A）と類円・棈円 形の核を呈し，極性・結合性のみられないStromal B

(Pap. 染色, 63×3.3)

Stromal Bが直接付着して取れたとみられる，濃染性 で小型の細胞である.

次に上皮細胞集塊としては，子宮内腔を覆う一層の 被覆円柱上皮とそれに連なる体内膜腺が考えられる。 前者の被覆円柱上皮は，増殖期初期次採取されると核 密度は高いが一層で，上皮の直下に Stromal A および $\mathrm{B}$ の間質細胞が数層重なるように直接付着して認めら れる。体内膜腺は，トンネル状になった腺の周囲に第 三の間質細胞が腺を構成する細胞に対し横に寝るよう な形で付着して認められる(写真 9，10)。正常の体内 膜腺では周囲に十分量の間質細胞を有しているため, これが引き抜かれて細胞標本上にのる場合には，通常 集塊の最外層に第三の間質細胞が直接付着してみられ るものと思われる。いいかえればこのような状態で腺 様集塊がみられる時には，ほほ正常の体内膜腺ではな いかと考えている（図1a）。

一方, 内膜増殖症や $\mathrm{G} 1$ 腺癌などでは, 腫瘍細胞が 腺管内または子宮腔内に乳頭状ないし樹枝状に增殖す 


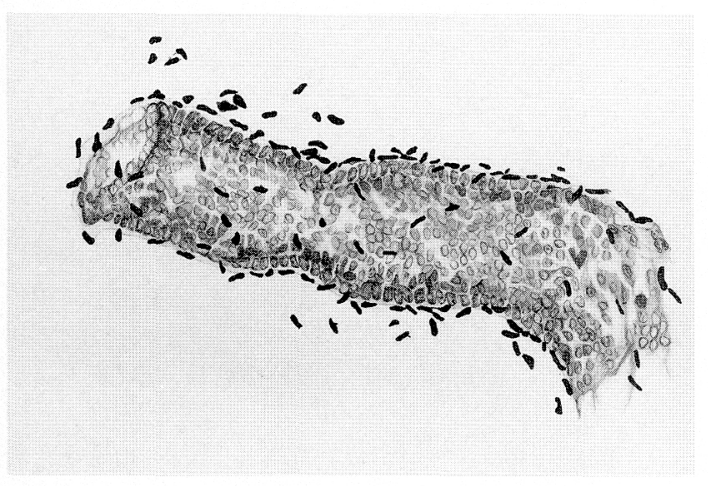

写真 9 正常体内膜腺のシェーマ

微動装置を上下させることにより，トンネル状になった腺管に 濃染した第三の間質細胞が横に寝るように直接付着しているの が認められる

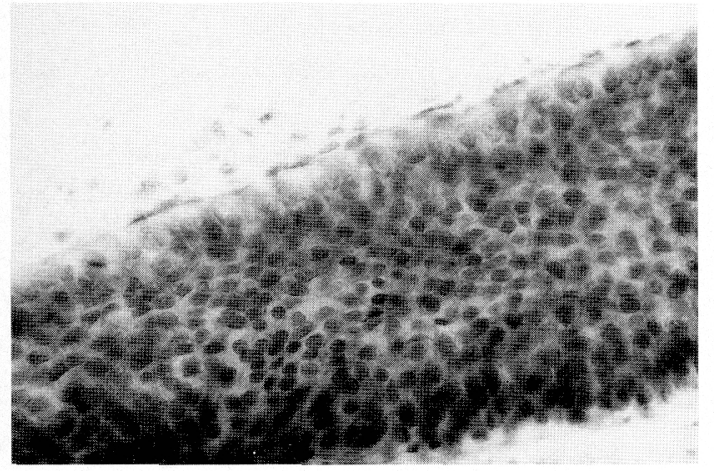

写真 10 正常体内膜腺の細胞像 (Pap. 染色, $40 \times 3.3$ )

るのが常であるが，このような所から取れてきた細胞 集塊においては当然のことながら細胞集塊周囲に間質 細胞の直接付着はみられない。すなわち，周囲に第三 の間質細胞を伴わない乳頭状ないし樹枝状細胞集塊が 目立つ場合には，子宮内膜の増殖性病変の存在を考え る必要があると思われる (図 $1 \mathrm{~b}$ )。今回のわれわれの 研究でも, 腺腫性増殖症では乳頭状集塊が, G 1 腺癌で は樹枝状集塊が高頻度に出現している，ただし，増殖 期内膜に扎いも $25.0 \%$ に乳頭状細胞集塊がみられ たが，これは増殖期の組織像で認められる腺腔内への 腺上皮の乳頭状増殖に由来しているものと考えられ る.な抏, 乳頭状集塊と樹枝状集塊の違いについては, これも推論の域をでないが，同じ乳頭状増殖において も $\mathrm{G} 1$ 腺癌では盛んに分岐・発達する血管をその芯に 含むため,これが Stromal A となってみられるのでは ないか，逆に増殖症ではこれが不明瞭なため樹枝状集 塊よりは乳頭状集塊が主体となるのではないかと考え

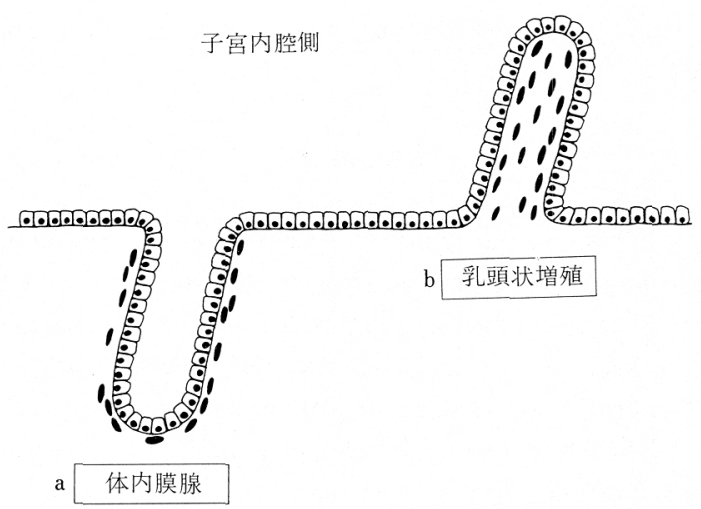

図 1 体内膜腺と子宮腔内乳頭状増殖のシェーマ $\mathrm{a}$ : 体内膜腺 $\mathrm{b}$ ：乳頭状增殖

られる。

構造異型をみる際には集塊の形態のみならず，集塊 内の腺腔の有無も重要である. 正常体内膜に比べて, 内膜増殖症, G 1 腺癌となるにつれて, 内膜腺の分岐は 密で複雑になることはこれまでの連続組織切片による 立体構築の検討からも明らかである31.したがって, 細 胞標本においても細胞集塊内の腺腔が癌になるほど高 頻度で，またその数も多くなるものと思われる。実際， 今回の研究においても集塊内腺腔の密な検体は腺腫性 増殖症で，23.1\%，G 1 腺癌で $84.6 \%$ と高頻度にみら れたが，増殖期内膜では $0 \%$ であった。

腺腔の back to back や腺腔内の乳頭状増殖とした 所見も同様で, 増殖期内膜では 1 例も及られなかった のに対し, 腺腫性増殖症ではそれぞれ $23.1 \%$ と 34.6\%, G 1 腺癌では 88.5\%と $84.6 \%$ に認められた. G 1 腺癌では集塊の大部分が小腺腔で占められること が多く，また腺腔内に乳頭状増殖したものがさらに発 育し, 相対する壁へ融合して行く像も頻繁に認められ る (写真 7 ).

以上，体内膜細胞診による腺腫性増殖症と G 1 腺癌 の質的判定には，第一に正常の体内膜被覆上皮，体内 膜腺および三種類の間質細胞を十分把握し，腺腫性増 殖症以上の病変に対しては顕微鏡の微動装置を十分に 活用した三次元的な観察を行い, (1) 乳頭状および樹枝 状細胞集塊, (2) 集塊内多層化腺腔, (3) 腺腔の back to back, (4) 腺腔内乳頭状増殖などの構造異型をみるこ とがきわめて重要であると思われる。

本論分の要旨は, 第 31 回日本臨床細胞学会総会 (長崎)におい て発表した。 
本研究は, 財団法人東京都がん検診センターの研究費により研 究したものである.

\section{Summary}

In order to clarify the cytologic features of endometrial adenocarcinoma (G 1) and adenomatous hyperplasia, a total of 68 samples, consisting of 26 samples of endometrial adenocarcinoma (G 1), 26 of adenomatous hyperplasia and 16 of proliferative-phase endometrium were analyzed. The samples obtained with the endocyte or aspiration were wa shed in physiological solution, centrifuged, and then smeared on slides for fixation and staining. The results were as follows :

1. The incidence of arborescent fragments in which the epithelial cells were arranged on stalks of spindle cells (Stromal A) was 73.1\% in endometrial adenocarcinoma (G 1), $3.8 \%$ in adenomatous hyperplasia and $0 \%$ in proliferativephase endometrium. Papillary cellular clusters were observed in all samples of both carcinoma and hyperplasia, but in $25.0 \%$ of normal endometrium.

2. The incidence of clusters with closely packed lumina was $84.6 \%$ in carcinoma and $23.1 \%$ in hyperplasia, while these clusters were scarcely observed in normal endometrium.

3. Intraluminal papillary projections in cellular clusters were found in $84.6 \%$ of carcinoma, $34.6 \%$ of hyperplasia, and none in normal endometrium.

This study concludes that the accurate observation on architectural abnormalities of cellular clusters is useful for cytodiagnosis of uterine endometrium.

\section{文献}

1）藤田＼cjkstart彬・他：エンドサイト法による子宮内膜細胞診の 検討, 日臨細胞誌, $29: 8 \sim 15,1990$.

2）井上悟・他：子宮体癌およびその前癌病変の細胞診, 日臨細胞誌，23：524〜 531, 1984.

3）石井保吉・他：子宮内膜腺癌および関連病変における組 織構築の解析（第 I 報)，日臨細胞誌，29：487〜 492, 1990.

4）岩成 治・他：子宮内膜細胞診の scoring に関する検 討, 日臨細胞誌, $29 ： 869 \sim 876,1990$.

5) Kashimura, M., et al. : Cytologic findings in endometrial hyperplasia, Acta Cytol., 32:335 340, 1988.

6）蔵本博行・他：体癌のスクリーニング法としての細胞 診, 産婦治療, $52 ： 440 \sim 444,1986$.

7）根本裕樹・他：子宮体癌細胞診に招ける Criteria, 日臨細 胞誌, $22 ： 720 \sim 725,1983$.

8) Ng, A.B.P. and Reagan, J.W.: Significance of endometrial cells in the detection of endometrial carcinoma and its precursors, Acta Cytol., 18:356 361, 1974.

9）大野英治・他：細胞診による子宮体癌の組織分化度判 定, 日臨細胞誌, $27 ： 449 \sim 458,1988$.

10) Reagan, J.W. : Can screening for endometrial cancer be justified?, Acta Cytol., $24: 87 \sim 89,1980$.

11）米本行範 - 他：高分化型子宮体部腺癌の内膜吸引細胞像 について，日臨細胞誌，29：16〜20, 1990. 